\title{
Study of Resource Productivity and Resource Use Efficiency of Wheat in Solapur District of Maharashtra State
}

\author{
S.N. Sable ${ }^{1}$, K.V. Deshmukh ${ }^{2 *}$ and R.D. Shelke ${ }^{3}$ \\ Department of Agricultural Economics \\ College of Agriculture, Latur, India \\ *Corresponding author
}

\begin{tabular}{|l|}
\hline Ke y w o r d s \\
$\begin{array}{l}\text { Resource } \\
\text { productivity, } \\
\text { Resource use } \\
\text { efficiency, MVP. }\end{array}$ \\
\hline Article Info \\
\hline $\begin{array}{l}\text { Accepted: } \\
\text { 17 June } 2018 \\
\text { Available Online: } \\
\text { 10 July } 2018\end{array}$ \\
\hline
\end{tabular}

\section{Introduction}

Wheat (Triticum aestivum L.) belongs to Gramineae family. It is cultivated in rabi season. Origin of wheat is South West Asia (Turkey). Only four species of wheat are cultivated in India. The common bread wheat
(Triticum aestivum) is the most important species, occupying more than 90 per cent of the total area in the country. Wheat grain is staple food used to make flour for, flat and steamed breads, biscuits, cookies, cakes, breakfast cereal, pasta, noodles and fermentation to make beer, other alcoholic 
beverages or bio fuel. Wheat grains are grind into flour and consumed in the form of chapatti. Hard wheat is used for manufacturing rawa, suji and shewaya. Wheat is planted to a limited extend as a forage crop for livestock, and its straw can be milled to leave just the endosperm for white flour. The concentrated sources of vitamins, minerals and protein, while the refined grain is mostly starch. World produced 751.36 million tonnes of wheat from an Area of 221.73 million hectares and Productivity is 3.39 million metric tonnes in 2016-17. China is the largest wheat producing country in the world. China produces 130 million tonnes of wheat in 20162017. India is the second largest producer of wheat in world. India produces 87 million tonnes of wheat from 30.22 million hectares of land in 2016-2017 and consumes 86.2 million tonnes of wheat ranking them as the second largest consumer of wheat in the world. In Maharashtra wheat is grown in 7 Lakh hectares with average productivity of 13.2 quintals per hectares against the national average of about 26.5 quintals per hectares.(Source: State of Indian Agriculture 2016-17). In Solapur district the area of wheat crop is 500 hectares with production of 700 M.T. and productivity is $1400 \mathrm{~kg}$ per hectares in 2016-17.(Source: District Statistical Report 2016-17).

\section{Objective}

To estimate resource productivity and resource use efficiency in wheat production

\section{Materials and Methods}

Multistage sampling design was adopted in selection of district, tehsils and villages. In all, 60 wheat growers were selected for the study. Tabular analysis, frequency and percentage methods were used to analyze and compare the data in present study. Marketing cost and market margin of different functionaries were estimated from the data collected from them. The data were collected during the year 2017 18.

\section{Functional analysis}

The resource productivity and resource use efficiency was achieved by application of functional analysis. In the functional analysis linear and Cobb-Douglas production functions were used for data. On the basis of goodness of fit $\left(\mathrm{R}^{2}\right)$ Cobb-Douglas production function (non-linear) was used to determine the resource productivity in wheat production. The data were therefore, subjected to functional analysis by using the following form of equation.

$\mathrm{Y}=\mathrm{aX}_{1}^{\mathrm{b} 1} \cdot \mathrm{X}_{2}^{\mathrm{b} 2} \cdot \mathrm{X}_{3}^{\mathrm{b} 3} \ldots \ldots \ldots \mathrm{X}_{\mathrm{n}}^{\mathrm{bn}} \cdot \mathrm{e}^{\mathrm{u}}$

The equation fitted was of the following formula.

$\hat{\mathrm{Y}}=\mathrm{aX}_{1}{ }^{\mathrm{b} 1} \cdot \mathrm{X}_{2}^{\mathrm{b} 2} \cdot \mathrm{X}_{3}^{\mathrm{b} 3} \cdot \mathrm{X}_{4}{ }^{\mathrm{b} 4} \cdot \mathrm{X}_{5}^{\mathrm{b} 5} \cdot \mathrm{X}_{6}^{\mathrm{b} 6} \cdot \mathrm{X}_{7}{ }^{\mathrm{b} 7} \cdot \mathrm{X}_{8}{ }^{\mathrm{b} 8}$

Where,

$\hat{\mathrm{Y}} \quad=$ Estimated yield of wheat in quintals per farm,

a $\quad=$ Intercept of production function

bi $=$ Partial regression coefficients of the respective resource

variable $(\mathrm{I}=1,2,3 \ldots . .8)$

$\mathrm{X} 1=$ Area of the crop in hectares

$\mathrm{X} 2=$ Machine labour in hours per farm

$\mathrm{X} 3=$ Nitrogen in $\mathrm{kg}$ per farm

$\mathrm{X} 4=$ Potash in $\mathrm{kg}$ per farm

$\mathrm{X} 5 \quad=$ Seed in $\mathrm{kg}$ per farm 
X6 = Plant protection in Rs per farm

X7 = Human labour in man days per farm

The marginal value of productivity of resource indicates the addition of gross value of farm production for a unit increase in the ' $i$ 'th resources with all resources fixed at their geometric mean levels. The MVP of various inputs is worked out by the following formula.

$\mathrm{MVP}=b_{i} \mathrm{P}_{\mathrm{y}} \frac{\overline{\mathrm{Y}}}{\overline{\mathrm{X}}}$

Where,

B $=$ Regression coefficient of particular independent variable

$\mathrm{X}=$ Geometric mean of particular independent variable

$\mathrm{Y}=$ Geometric mean of dependent variable

$\mathrm{P}_{\mathrm{y}} \quad=$ Price of dependent variable

$\sum \mathrm{bi}=$ Returns to scale

\section{Results and Discussion}

Resource productivity and resource use efficiency in wheat crop

\section{Estimates of Cobb-Douglas production function in wheat production}

Linear and Cobb-Douglas production function was fitted and on the basis of goodness of fit $\left(\mathrm{R}^{2}\right)$ Cobb-Douglas production function was selected. To selected independent variables used in the production function, correlation matrix for wheat crop was developed. On the basis of non-significant correlation coefficients, some of the variables were dropped. Similarly in order to solve problem of multicollinearity, the correlation coefficient among independent variables were which had less than the value of multiple determinations was taken in to consideration and one of the variables was dropped. Thus, remaining independent variables were used in specific production. Cobb-Douglas production function was used. The regression coefficient of the Cobb-Douglas function are the elasticities of production and easy to determine the returns to scale in production function (Table 1).

\section{Elasticity of production}

The result revealed that, coefficient of multiple determinations $\left(\mathrm{R}^{2}\right)$ was 0.935 which indicated 93.00 per cent effect of all independent variables together in wheat production. F-value was 63.26 which were highly significant.

Return to scale was 0.32 which indicated increasing return to scale. Among the individual independent variables, partial regression coefficient of area under wheat was 2.52 which positive and significant at 5 per cent level of significance. Similarly, partial regression coefficient of bullock labour was 2.20 which also positive and significant. Partial regression coefficient of irrigation was positive and significant at 5 per cent level i.e. 2.53 .

\section{Marginal productivity}

It was observed that marginal product with respect to area under wheat was 0.021 which means that in addition of one hectare of land to geometric mean which is gives production of wheat by 0.021 quintals. Marginal product of potash was 8.94 which means that when there was addition of one quintal of potash it give additional product by 8.94 quintals. 
Table.1 Estimation of Cobb-Douglas production function in wheat production

\begin{tabular}{|c|c|c|c|c|c|c|c|c|c|}
\hline $\begin{array}{l}\text { Sr. } \\
\text { No. }\end{array}$ & $\begin{array}{l}\text { Independent } \\
\text { Variable }\end{array}$ & $\begin{array}{l}\text { Regression } \\
\text { coefficient } \\
\text { (bi) }\end{array}$ & $\begin{array}{l}\text { Standard } \\
\text { error bi } \\
\text { (SE) }\end{array}$ & $\begin{array}{c}\text { 't' } \\
\text { value }\end{array}$ & $\begin{array}{l}\text { Geometric } \\
\text { Mean of } \\
\text { input (xi) }\end{array}$ & $\begin{array}{l}\text { Marginal } \\
\text { product } \\
\text { (q) }\end{array}$ & $\begin{array}{l}\text { Marginal } \\
\text { value } \\
\text { product } \\
\text { (Rs.) }\end{array}$ & $\begin{array}{c}\text { Price } \\
\text { of } \\
\text { input } \\
\text { (Rs.) }\end{array}$ & $\begin{array}{l}\text { MVP } \\
\text { to } \\
\text { price } \\
\text { ratio }\end{array}$ \\
\hline 1 & $\begin{array}{l}\text { Area under } \\
\text { wheat } \\
\text { (ha/farm) }\end{array}$ & 0.001 & 0.0007 & $2.52 *$ & 0.68 & 0.021 & 5460 & 2600 & 2.10 \\
\hline 2 & $\begin{array}{l}\text { Hired human } \\
\text { labour (man } \\
\text { day/farm) }\end{array}$ & -0.034 & 0.109 & -0.318 & 23.14 & 0.022 & -57.2 & 200 & -0.28 \\
\hline 3 & $\begin{array}{l}\text { Bullock labour } \\
\text { (pair day/farm) }\end{array}$ & 0.160 & 0.072 & $2.203^{*}$ & 1.57 & 1.510 & 392.6 & 800 & 0.49 \\
\hline 4 & $\begin{array}{l}\text { Machine labour } \\
\text { (hours/farm) }\end{array}$ & 0.194 & 0.102 & 1.908 & 6.07 & 0.476 & 123.7 & 500 & 2.47 \\
\hline 5 & Seed (kg/farm) & 0.187 & 0.137 & 1.368 & 61.85 & 0.045 & 117.0 & 66 & 0.23 \\
\hline 6 & $\begin{array}{l}\text { Nitrogen } \\
\text { (Kg/farm) }\end{array}$ & -0.283 & 0. & -1.077 & 47.09 & 0.089 & -231.4 & 13 & -1.77 \\
\hline 7 & $\begin{array}{l}\text { Potash } \\
\text { (Kg/farm) }\end{array}$ & 0.102 & 0.059 & 1.719 & 22.68 & 8.940 & 232.0 & 28 & 1.78 \\
\hline 8 & $\begin{array}{l}\text { Plant protection } \\
\text { (lit/farm) }\end{array}$ & -0.010 & 0.125 & -0.086 & 0.42 & 7.45 & -193.7 & 130.5 & -1.47 \\
\hline 9 & $\begin{array}{l}\text { Irrigation }\left(\mathrm{M}^{3}\right. \\
\text { /farm) }\end{array}$ & 0.001 & 0.0007 & $2.53^{*}$ & 3384.57 & 0.015 & 10.40 & 3.8 & 2.73 \\
\hline
\end{tabular}

Intercept $\log (\mathrm{a}) \quad$..... 3.255

Note: Geometric mean (Y) of wheat production was 14.91q R $\quad 0.935$ per farm and price was Rs. 2600/q

F-value ...... 63.26

Return to scale $\left(\sum \mathrm{bi}\right) \ldots \ldots . . \quad 0.32$

*Significant at 5 per cent level, ** Significant at 1 per cent level.

Marginal product of plant protection was 7.45 which means that when there was addition of one $\mathrm{kg}$ of plant protection it give additional product by 7.45 quintals. Marginal product of bullock labour was 1.51 it indicated that when there was use of one man day of bullock labour give additional product of wheat by 1.51 quintals.

\section{Resource use efficiency}

Results revealed that, marginal value product (MVP) of area under wheat was found to be
Rs. 5460 and marginal input cost of land under wheat was Rs. 8074.54 hence MVP to marginal input cost ratio was 0.68. MVP to marginal input cost ratio of Irrigation was found to be 2.73 which was highest followed by machine labour (2.47), Potash (1.78), Bullock labour (0.49) and seed (0.23). It was cleared that, higher MVP to marginal input cost ration was greater chance to increase these resources. So the results inferred that there was greater chance to increase Irrigation, Potash, Bullock pair and seed utilization. 
It was clear that, MVP to marginal input ratios of these variables was large and away from unity. Thus, it was obvious that, the expenditure on area under wheat, Irrigation and Potash can be increased. These resources were found in underutilization of wheat production. On the contrary, the expenditure on Hired human labour, and Nitrogen can be reduce because overutilization of these resources in wheat production on overall farm. These results were conformity with the results obtained by Kauthekar et al., 2015.

In conclusion, the coefficient of multiple determinations $\left(\mathrm{R}^{2}\right)$ was 0.935 which indicated 93.00 per cent effect of all independent variables together in wheat production. F-value was 63.26 which were highly significant. Return to scale was 0.32 which indicated increasing return to scale. Among the individual independent variables, partial regression coefficient of area under wheat was 2.52 which positive and significant at 5 per cent level of significance. It was cleared that, higher MVP to marginal input cost ration was greater chance to increase these resources. MVP to marginal input ratios of these variables was large and away from unity. Thus, it was obvious that, the expenditure on area under wheat, Irrigation and Potash can be increased. These resources were found in underutilization of wheat production. On the contrary, the expenditure on Hired human labour, and Nitrogen can be Reduce because overutilization of these resources in wheat production on overall farm.

\section{References}

Gautam A. N., Sahu R. M., Nidhi Sirothiya, 2017. Resource Use Efficiency of Wheat in Betul District of Madhya Pradesh. Uni. J. of Agril. Res. 5(1): 57-60.

Harish A. Patil Dr. Vanita K. Khobarkar, 2013. Resource Use Efficiency in Wheat Production of Amravati Division. Ind. J. of Appl. Res. 3(7):1011.

Kauthekar P. U., Pawar B. R. and Kolambkar R. A., 2015. A study of resource Productivity and resource use efficiency in wheat production. Int. J. of Com. and Bus. Manag. 8(2):195198.

Narvariya R., Sharma A., Patidar A, Raghuvanshi J.S. and Narvariya R., 2015. Resource use efficiency in wheat production in Narmadapuram division, Eco. Env. \& Cons. 21(27):149-151.

Pagare K. H., More S. S., Ravi Shrey and Pallab Debnath, 2013. Resource productivity, resource use efficiency and return to scale of small, medium and large Rabi jowar growers in Marathwada region. Int. J .of Com. and Busi. Manag. 6(2):206-210.

\section{How to cite this article:}

Sable, S.N., K.V. Deshmukh and Shelke, R.D. 2018. Study of Resource Productivity and Resource Use Efficiency of Wheat in Solapur District of Maharashtra State. Int.J.Curr.Microbiol.App.Sci. 7(07): 2170-2174. doi: https://doi.org/10.20546/ijcmas.2018.707.256 